\title{
Effect of Soybean Varieties under Different Land Configurations on Soil Moisture Status
}

\author{
Ankita Negi ${ }^{1}$, Aaradhna Chilwal ${ }^{2}$ and Reshma Bora ${ }^{3 *}$ \\ ${ }^{1}$ Department of Agronomy, GBPUA\&T, Pantnagar, Uttarakhand, India \\ ${ }^{2}$ Punjab Agriculture University, Ludhiana, India \\ ${ }^{3}$ Department of Agriculture, UCBMS\&H, Dehradun, Uttarakhand, India \\ *Corresponding author
}

\begin{tabular}{|l|}
\hline K e y w o r d s \\
$\begin{array}{l}\text { Land configuration, Flat } \\
\text { bed, Ridge and furrow, } \\
\text { Raised bed, Mean } \\
\text { moisture content, Dry } \\
\text { spell }\end{array}$ \\
\hline Article Info \\
\hline $\begin{array}{l}\text { Accepted: } \\
15 \text { October } 2018 \\
\text { Available Online: } \\
10 \text { November } 2018\end{array}$ \\
\hline
\end{tabular}

\section{A B S T R A C T}

Soybean is a rainy season crop but is highly sensitive to excess moisture conditions. The excess moisture or water logging conditions during monsoon season create unfavourable conditions for growth, such as reduced porosity which in turn reduces soil aeration, reduced root growth, hampered nodulation, reduced nutrient uptake affecting the physiology and biochemistry of a plant adversely which ultimately reflects on its productivity. Varieties and land configuration techniques are the two major factors for enhancing soybean yield. The present study was thus planned to analyse the effect of soybean varieties under different land configurations in mollisols of Himalayan tarai on soil moisture status. The experiment was conducted during the kharif season of 2017, in C5 block of N.E. Borlaug Crop Research Centre of G.B. Pant University of Agriculture and Technology, Pantnagar (Uttarakhand). Treatments consisted of three land configurations (Flat bed, ridge and furrow and raised bed) and varieties (PS-1092, PS-1225 and PS-1347) were set out in split plot design keeping land configurations in main plot and varieties in sub plot with three replication. After heavy rain fall, the moisture content was more in top soil layer than lower layer irrespective of the treatments. The mean value was higher by $11.5 \%$ in $0-15 \mathrm{~cm}$ layer $(14.6 \%)$ than $15-30 \mathrm{~cm}$ layer $(13.1 \%)$. Among land configurations, flat bed recorded the highest moisture content in both the layers followed by ridge \& furrow method and raised bed method. During dry spells, the mean moisture content in top layer was $10.3 \%$ and in second layer $10.1 \%$. In top layer it ranged from $9.8 \%$ in raised bed method to $10.7 \%$ in flat bed method. Varieties failed to bring substantial impact on soil moisture content in both the layers, neither after rainfall nor during dry spells. The study revealed the importance of land configuration in maintaining positive soil moisture status.

\section{Introduction}

Globally, soybean is cultivated over an area of 121.9 million ha with production of 342.6 million tons and productivity of $2800 \mathrm{~kg} / \mathrm{ha}$. In India, it is cultivated over an area of 11.5 million ha with production of 10.6 million tons and productivity of $922 \mathrm{~kg} / \mathrm{ha}$ (IISR, Indore 2016-17). In India, it has emerged as major oilseed crop over a period of time. Owing to its vast multiplicity of uses as food and industrial products, it is known as wonder 
crop (Tripathi and Mishra, 2005). This crop can also serve as an alternate in crop diversification under upland conditions in rice-wheat system. It can be grown in varied agro-climatic conditions, hence has emerged as one of the important commercial crop in many countries. Despite availability of numerous high yielding varieties of soybean, the average grain yield is still low in India. Factors responsible for low yield of soybean include untimely sowing, low seed viability, poor soil fertility, poor drainage, weed infestation, pest and disease attack etc. In northern India, soybean is taken during Kharif rainy season (June-November). During this period on an average $1345 \mathrm{~mm}$ rainfall is received and max rainfall period coincides with the active vegetative phase of the crop. Soybean, though is a rainy season crop but is highly sensitive to excess moisture conditions. Therefore, fast removal of excess water/water logging is necessary to protect the crop from damage. Water logging is detrimental to root growth and nodulation both. The excess moisture or water logging conditions during monsoon season create unfavourable conditions for growth, such as reduced porosity which in turn reduces soil aeration, reduced root growth, hampered nodulation, reduced nutrient uptake affecting the physiology and biochemistry of a plant adversely which ultimately reflects on its productivity. Land management system plays a major important role in minimizing soil erosion and improving water use efficiency of field crops. Easy and uniform germination as well as growth and development of plant are provided by manipulation of sowing method. Land configuration increases water use efficiency and also increases availability of nutrients to crops (Chiroma et al., 2008). Land configuration viz., ridge and furrow and bed systems have been known to dispose additional rain water (runoff) faster than flat beds as in former two methods, furrows act as drainage channel. Rain water falling on the ridges or on the beds goes down to furrows, which carries it out from the fields. Consequently, the root zone of the crop receives less water in ridges and furrow and bed systems compared to flat beds. Land configuration is the prime work for better growth and development of any crop. Land configuration decides the effectiveness of the crop management practices regarding application of nutrient, irrigation, weed management etc. Proper land configuration according to the climatic conditions of the region viz., heavy rainfall area or drought prone areas or area with salinity hazards acts as management practice to the crop (Deshmukh et al., 2016). Land configurations for sowing of soybean have been used to enhance in situ rain water conservation and minimize soil erosion and nutrient losses during water stressed period and sometime act as drainage channels during water logged conditions (Kamboj et al., 2008). Water logging can be managed or mitigated to some extent by adopting or altering some suitable package of practices. Among the technologies planting technique is the most important, as change in layout methods will be useful for emergence and establishment of soybean which contribute to overall crop performance. The location of Pantnagar falls under humid subtropical climate of high temperature, high rainfall and high humidity which favours disease, pest incidence, and preponderance of weeds finally leading to reduced crop stand. On the other hand, moisture deficiency during the post-monsoon period adversely affects the development of reproductive organs leading to depressed yields (Kantwa et al., 2005). Lakpale and Tripathi (2012) reported that the bulk density of soil was estimated minimum in ridge and furrow method $(1.32 \mathrm{~g} / \mathrm{cc})$ as compared to broad-bed plantings (1.36-1.37 $\mathrm{g} / \mathrm{cc})$ and flat planting $(1.48 \mathrm{~g} / \mathrm{cc})$. There are numerous high yielding varieties of soybean and above studies revealed the role of land configuration in maintaining positive water 
balance in soil. So the present study was planned to estimate the interaction effect of varieties and land configuration on moisture status of soil.

\section{Materials and Methods}

The field experiment was conducted in Kharif season of 2017 in C5 block at the Norman E. Borlaug Crop Research Centre of GovindBallabh Pant University of Agriculture \& Technology, Pantnagar (U.S. Nagar), Uttarakhand, India. Geographically, Pantnagar is situated in the Tarai area which is narrow belt in the foothills of Shivalik range of Himalayas at $29^{\circ} \mathrm{N}$ latitude and $79.5^{\circ} \mathrm{E}$ longitude and at an altitude of $243.8 \mathrm{~m}$ above mean sea level. The experimental soil was low in available nitrogen, medium in organic carbon but high in phosphorus and medium in potassium. The experiment was conducted in split plot design with 3 land configurations (Flat sowing, Ridge and furrow sowing and Raised bed sowing) in main plot and 3 varieties of soybean (PS -1092, PS -1225 and PS -1347) in sub-plot.

In flat sowing soybean was sown in rows open $45 \mathrm{~cm}$ apart. Land configuration viz., ridge and furrow and raised beds were made manually with small spade. Distance between center to center of furrows was $45 \mathrm{~cm}$ in ridge and furrow system. One row of soybean was sown on the ridge. In raised bed system, distance between center to center of furrows was $90 \mathrm{~cm}$. Two rows of soybean were sown on a bed at $30 \mathrm{~cm}$ apart. Thinning was done between 20-22 days after sowing (DAS) to maintain spacing between $10 \pm 2 \mathrm{~cm}$.

Varieties tested were: PS-1092- purple flowers, yellow seed colour with black hilum colour, tawny pubescence, determinate growth type, pod colour is brown, spherical seed shape, short plant height, erect growth habit with pointed ovate leaf shape. The duration of its growth is 118-120 days. Recommended for tarai and bhabar region of UP, Uttarakhand and upto mid hills of Uttarakhand. PS-1225 white flowers, yellow seed colour with brown hilum colour, grey pubescence, semideterminate growth type, pod colour is yellow, spherical seed shape, medium plant height, semi-erect growth habit with pointed ovate leaf shape. PS-1347 - white flowers, yellow seed colour with brown hilum colour, tawny pubescence, determinate growth type, pod colour is brown, elliptical seed shape, short plant height, semi-erect growth habit with lanceolate leaf shape. The duration of its growth is 120-125 days. The suitable areas of its cultivation are Northern Plain Zone, UP, UK, Delhi, Punjab, etc.

\section{Results and Discussion}

Soil moisture in top soil layers $(0-15 \mathrm{~cm}$ and $15-30 \mathrm{~cm})$ was estimated heavy rainfall and during dry spells. The data on soil moisture content is presented in table 1 and 2. After heavy rain fall, the moisture content was more in top soil layer than lower layer irrespective of the treatments. The mean value was higher by $11.5 \%$ in $0-15 \mathrm{~cm}$ layer $(14.6 \%)$ than $15-30$ $\mathrm{cm}$ layer $(13.1 \%)$. The higher moisture content in top layer may be due more absorption of rain water by this layer as it is in direct contact with the rain water. Further it has better porosity to store more water. Soybean is a spreading type crop with high foliage, which might have helped to curtail the evaporation loss causing more moisture in the top layer. Among land configurations, flat bed recorded the highest moisture content in both the layers followed by ridge and furrow method and raised bed method. In land configuration treatments, furrows are opened to remove excess water. Fast removal of water by the furrows might have resulted in quick drainage of water. Therefore, the moisture content was low in these methods. Among varieties, the moisture content did not vary much in both the layers. 
Table.1 Layer wise soil moisture content in percent (mean) 2 days after heavy rain under different land configurations and varieties

\begin{tabular}{|c|c|c|}
\hline \multirow{2}{*}{ Treatment } & \multicolumn{2}{|c|}{ Depth (cm) } \\
\hline Land configuration & $0-15$ & $15-30$ \\
\hline Flat bed & 15.30 & 14.50 \\
\hline Ridge \& Furrow & 14.70 & 12.60 \\
\hline Raised bed & 13.80 & 12.30 \\
\hline Variety & 14.40 & 13.00 \\
\hline PS-1092 & 14.90 & 13.30 \\
\hline PS-1225 & 14.60 & 13.20 \\
\hline
\end{tabular}

Table.2 Layer wise soil moisture content (mean) during dry spells under different land configurations and varieties

\begin{tabular}{|r||c|c|}
\hline \multicolumn{2}{|c|}{ Treatment } & \multicolumn{2}{|c|}{ Depth (cm) } \\
\hline Land configuration & $0-15$ & $15-30$ \\
\hline Flat bed & 10.7 & 10.2 \\
\hline Ridge \& Furrow & 10.5 & 10.4 \\
\hline Raised bed & 9.8 & 9.7 \\
\hline Variety & & 10.2 \\
\hline PS-1092 & 10.4 & 10.0 \\
\hline PS-1225 & 10.2 & 10.1 \\
\hline PS-1347 & 10.5 & \\
\hline
\end{tabular}

It was slightly more in variety PS-1225, which may be attributed to its vigorous canopy curtailing more evaporation loss compared to other varieties.

Soil moisture content estimated during dry spells showed almost the similar trend but the magnitude of variation among treatments was less as compared to 48 hrs after heavy rainfall. During dry spells, the mean moisture content in top layer was $10.3 \%$ and in second layer $10.1 \%$.

In top layer it ranges from $9.8 \%$ in raised bed method to $10.7 \%$ in flat bed method. Data suggests that during dry spells flatbed also loses excess moisture through ET process.
Higher moisture loss from top layer may be credited to more root biomass.

Not much variation in soil moisture content was observed among varieties. Slightly lower moisture content in variety PS-1225 was noted, which may be due to higher root biomass compared to other varieties.

It was found from the study that land configurations have significant effect on moisture status of the soil. Flat beds led to higher moisture content but raised bed and furrow method led to favourable moisture balance by simultaneously acting as drainage channels. Varieties however showed little effect on soil moisture status and whatever 
difference was observed it was only due to genetic characters of varieties. No significant interaction was achieved between the two studied factors.

\section{References}

Chiroma, A.M., Alhassan, A.B., and Khan, B. 2008. Yield and water use efficiency of millet as affected by land configuration treatments. J. Sustainable Agric., 32 (2): $321-333$.

Deshmukh, S.P., Jayesh Vasase and Patel, A.M. 2016. A short review of land configuration to improve the plant growth, development and yield of cereals. Int. J. Interdisciplinary Res. Innovation, spp: (1-4).

Kamboj, B.R., Malik, R.K., Garg, R., Yadav, A., Singh, S., Goyal, N.K., Lathwal, O.P., Malik, Y.P., Mehla, O.P. 2008.
Bed planting - $\mathrm{a}$ novel technique to encourage multiple land use. Technical Bulletin (29). Directorate of Extension Education, CCS Haryana Agricultural University, Hisar, India, p-24

Kantwa, S.R., Ahlawat, I.P.S. and Gangaiah, B. 2005. Effect of land configuration, post monsoon irrigation and phosphorus on performance of sole and intercropped pigeonpea (Cajanus cajan). Ind. J. Agron. 50(4): 278-280

Lakpale, R., and Tripathi, V. K., 2012. Broadbed Furrow and Ridge and Furrow Method of Sowing under Different Seed Rates of Soybean (Glycine max L.) for High Rainfall Areas of Chhattisgarh Plains. Soybean Res., 10: 52 - 59.

Tripathi, A.K. and Mishra, A.K. 2005. Soybean nutritional studies. Journal food sci. tech. 42:111-119.

\section{How to cite this article:}

Ankita Negi, Aaradhna Chilwal and Reshma Bora. 2018. Effect of Soybean Varieties under Different Land Configurations on Soil Moisture Status. Int.J.Curr.Microbiol.App.Sci. 7(11): 2130-2134. doi: https://doi.org/10.20546/ijcmas.2018.711.239 